\title{
przemocy w ofiarniczych tragediach Cypriana Norwida
}

Norwid-romantyk czy Norwid-modernista? Jednoznaczne przypisanie twórczości autora Vade-mecum do romantyzmu lub modernizmu wciąż stanowi przedmiot gorących dyskusji wśród badaczy. Wyróżnić trzeba tu dwa dominujące stanowiska. Wedle tezy „romantycznej”, Norwida trzeba czytać jako reprezentanta drugiego pokolenia romantyków ${ }^{1}$. Romantyzm autora Assunty jednak znacznie różni się od romantyzmu jego wielkich poprzedników. Nie bez powodu w jednym z wierszy otwierających Vade-mecum Klaskaniem mając obrzękłe prawice - poeta, odnosząc się do ojców założycieli romantyzmu, dodawał: „Nie wziąłem od was nic, o! wielkoludy” (VMFert 2, $12)^{2}$. Wbrew opinii Jarosława Marka Rymkiewicza - niezwiązanego z badaniami norwidologicznymi i odznaczającego się głębokim niezrozumieniem twórczości autora Promethidiona - niepodobna mówić o epigoństwie i wtórności Norwidowskiej poetyki wobec twórczości reprezentantów pierwszego pokolenia romantyzmu³. Rację miała Zofia Stefanowska, wedle której

\footnotetext{
" Uniwersytet Łódzki, Instytut Filologii Polskiej, Katedra Literatury i Tradycji Romantyzmu, e-mail: mat.grabovski@gmail.com.

${ }^{1}$ Zob. Z. Stefanowska, Norwidowski romantyzm, [w:] taż, Strona romantyków. Studia o Norwidzie, Lublin 1993, s. 31.

${ }^{2}$ Wszystkie cytaty z tomu Vade-mecum cytuję za drugim wydaniem zbioru w opracowaniu Józefa Ferta (C. Norwid, Vade-mecum, oprac. J. Fert, wyd. 2, Lublin 2004).

3 "Ale Norwid - trzeba to wreszcie powiedzieć - to jeden z epigonów, jeden z tych, którzy zapisywali dziwacznymi gryzmołami marginesy kart, co już były zapisane przez Wielkie Duchy romantyzmu polskiego". J. M. Rymkiewicz, Juliusz Stowacki pyta o godzine, Warszawa 1989, s. 27. Sąd Rymkiewicza w swej ogólności i miałkości intelektualnej nie może być w żaden sposób traktowany jako reprezentatywny dla badań nad twórczością Norwida oraz - w szerszym kontekście - problematyką polskiego i europejskiego romantyzmu. Nazywanie twórczości Norwida - w całej jej wyjątkowości - romantycznym epigoństwem wynika z wręcz rażącej i kompromitującej nieznajomości spuścizny artystycznej autora Vade-mecum oraz bogactwa poetyk i kontekstów romantyzmu europejskiego.
} 
Norwid poszerza formułę polskiego romantyzmu ${ }^{4}$. Poszerza, zbliżając polski romantyzm do poetyki romantyzmu francuskiego ${ }^{5}$, ale również nadając polskiej literaturze swą własną, niepowtarzalną sygnaturę - owe „ciężkie norwidy". Jeżeli jednak przyjrzeć się dokładniej tej sygnaturze, zagłębić się w Norwidowską poetykę, to okazuje się, że kategoria romantyczności nie jest wystarczająca dla możliwie dokładnego, ale również i syntetycznego opisu bogactwa twórczości autora Assunty. Już samo zbliżenie poetyk polskiego i francuskiego romantyzmu ukazuje całą złożoność projektu jego poezji. Maciej Żurowski, Juliusz Wiktor Gomulicki, Magdalena Siwiec $^{6}$ i Wiesław Rzońca, porównując poetykę wierszy Norwida z poetyką utworów Baudelaire'a i Gautiera, zwrócili uwagę, że narodziny nowoczesnej francuskiej liryki, jakie miały miejsce pomiędzy zmierzchem parnasizmu a świtem symbolizmu, są przestrzenią rozkwitu Norwidowej poezjī Nie oznacza to jednak, że poeta zgadzał się z założeniami teoretycznymi i plonami artystycznymi obu prądów, co zauważył między innymi Janusz Maciejewski ${ }^{8}$.

Propozycje Żurowskiego i Gomulickiego skłoniły badaczy zachodnich - Rolfa Fiegutha i Hansa Roberta Jaussa - do postawienia tezy o nowoczesności Norwidowskiej liryki. Jednakże teksty obu badaczy, na co zwrócił uwagę Sławomir Rzepczyński ${ }^{9}$, stanowią tylko wstęp do dalszych, pogłębionych opracowań. Wiesław Rzońca postanowił kontynuować badania nad nowoczesnością Norwidowskiej liryki, stawiając mocną tezę o premodernizmie twórczości autora Vade-mecum, tym samym niejako zabierając go romantykom i oddając modernistom. Choć praca Rzońcy jest niezwykle ciekawa i inspirująca, część jego dość mocno stawianych tez budzi duże wątpliwości w środowisku badaczy ${ }^{10}$. Już Stefanowska zwracała uwagę, że

${ }^{4}$ Z. Stefanowska, Pisarz wieku kupieckiego i przemysłowego, [w:] taż, Strona romantyków, s. 46.

${ }^{5}$ Zob. M. Żurowski, Norwid i Gautier, [w:] Nowe studia o Norwidzie, red. J. W. Gomulicki i J. Z. Jakubowski, Warszawa 1961, s. 167-190.

${ }^{6}$ Zob. M. Siwiec, Norwid i Baudelaire. Komparatystyka przełomu, [w:] Komparatystyka dzisiaj, red. E. Kasperski i E. Szczęsna, t. 2, Warszawa 2011, s. 248-260.

${ }^{7}$ M. Zurowski, Norwid i Gautier, s. 170.

${ }^{8}$ Maciejewski skupił się na elementach różnicujących Norwidowską twórczość wobec parnasizmu i biedermeieru (zob. J. Maciejewski, Cyprian Norwid, Warszawa 1992, s. 118-121). Badacz przedstawił dość ciekawą tezę, wedle której dojrzała twórczość autora Promethidiona (rozpoczynająca się od 1848 r.) stanowiła radykalne odcięcie od poetyki romantyzmu, nie będąc jednocześnie uwikłana w żaden $\mathrm{z}$ antyromantycznych prądów literackich. Tym samym, wedle Maciejewskiego, Norwid nie był ani romantykiem, ani reprezentantem biedermeieru, pozytywizmu i parnasizmu. Norwidowska spuścizna artystyczna stanowiła jednak zapowiedź tych prądów, była wobec nich paralelna. Mankamentem tez stawianych przez badacza jest - podobnie jak w przypadku Rzońcy - zbyt sztywna definicja romantyzmu, która zawęża się tylko do zjawisk właściwych literaturze polskiej. Pomija natomiast bogactwo kontekstów właściwych choćby literaturze francuskiej, którą przecież Norwid znał wyśmienicie i która (co udowodnił Żurowski) stanowiła dla niego bardzo istotną inspirację.

${ }^{9}$ S. Rzepczyński, Norwid a nowoczesność, [w:] Romantyzm i nowoczesność, red. M. Kuziak, Kraków 2009, s. 215.

${ }^{10}$ Zob. E. Kasperski, Pseudo-Norwid, czyli co się komu podoba, "Studia Norwidiana” 2014, nr 32, s. 290-325; A. van Nieukerken, W czym zawiera się Norwidowski modernizm?, „Przegląd Humanistyczny" 2014, z. 2, s. 109-117; K. Samsel, Premodernizm, dekonstrukcjonizm, "proteuszowość" Norwida. Uwagi na marginesie dyskusji wokót Premodernizmu Norwida - na tle symbolizmu 
niepodobna mówić o Norwidzie jako o ojcu założycielu polskiego modernizmu $^{11}$. Norwid jako modernista i późny romantyk bliższy jest bowiem Charles'owi Baudelaire'owi, Paulowi Valéry'emu, czy szalonemu Comte de Lautréamontowi, niż poetom polskiej awangardy doby modernizmu ${ }^{12}$. Warto jednak pamiętać, że autor Vade-mecum pozostawał niezwykle krytyczny wobec literackich dokonań francuskiej bohemy ${ }^{13}$.

Podkreślenia wymaga, że rozważania Żurowskiego, Fiegutha, Jaussa i Rzońcy dotyczą przede wszystkim poetyki Norwidowskich wierszy. Uważam, że nowoczesność Norwida jest immanentną częścią całego jego dorobku intelektualnego, jego myśli oraz poglądów historiozoficznych. Słowem, Norwid jest nowoczesny nie tylko jako poeta, ale również, a może przede wszystkim, jako myśliciel. Zwracali na to uwagę najwybitniejsi badacze jego twórczości. Krytyka bujnie rozkwitającej nowoczesności z jej domami handlowymi, pasażami, przemianami w obrębie grup społecznych - ta problematyka jest kluczowa nie tylko dla poezji autora Vade-mecum, ale również dla jego twórczości dramatycznej, szczególnie tej tworzonej w późnej fazie biografii artystycznej. Jednakże nie chodzi tu przecież tylko o krytykę dorobku materialnego powstałego wraz z rozwojem kapitalizmu w drugiej połowie XIX wieku. Bardziej problematyczny i złożony jest syntetyczny opis procesów kulturowych, których manifestacją, według Norwida, jest późna nowoczesność ${ }^{14}$. Żeby zrekonstruować i nazwać te procesy, niezbędne jest wypracowanie odpowiednich narzędzi teoretycznych i odniesienie się do konkretnych metodologii. Próbę ich ustanowienia podejmie się w dalszej części studium, bowiem owe narzędzia teoretyczne i metodologia pozwolą na zrekonstruowanie stosunku Norwida do nowoczesności (szczególnie w jej późnej fazie) i ukazanie poety nie tylko jako pisarza romantycznego poszerzającego formułę polskiego romantyzmu, ale również autora i myśliciela modernistycznego, który w swej refleksji wyprzedził takich myślicieli jak Michael Foucault, Walter Benjamin, Theodor Adorno i René Girard. Jednoznaczne przypisanie twórczości Norwida do romantyzmu lub modernizmu, choć nie wydaje się możliwe, stanowi pretekst do ponownego zdefiniowania miejsca polskiego romantyzmu na mapie europejskiej nowoczesności.

literackiego drugiej połowy XIX wieku i wcześniejszych książek Wiesława Rzońcy, „Świat Tekstów. Rocznik Słupski" 2015, nr 13, s. 101-121.

${ }^{11}$ Z. Stefanowska, Pisarz wieku kupieckiego i przemystowego, s. 47.

12 „Gdyby w literaturze dwudziestowiecznej szukać przedłużenia linii, która reprezentowała twórczość Norwida w wieku XIX, trzeba byłoby zwrócić się nie do polskiej awangardy poetyckiej i nie do polskiego klasycyzmu, ale do Eliota i Valéry'ego. Do poetów historii i do poetów refleksji. Do poetów kultury i poetów synkretyzmu stylistycznego" (A. Lisiecka, Norwid - poeta historii, Londyn 1973, s. 11).

${ }^{13}$ M. Żurowski, Norwid i Gautier, s. 189.

${ }^{14}$ Pojęcie późnej nowoczesności przejmuję od A. Giddens, Nowoczesność i tożsamość, przeł. A. Szulżycka, Warszawa 2010. Co prawda, według Giddensa, początek późnej fazy nowoczesności należy datować na przełom XIX-XX wieku, jednakże pierwsze sygnały jej nadejścia, takie jak postępująca globalizacja ekonomiczna i kulturowa oraz powstawanie coraz bardziej skomplikowanych mechanizmów organizacyjnych, każą widzieć jej narodziny już w połowie XIX wieku. Nowoczesność w tej fazie została ujęta przez Norwida w znanej frazie „wiek kupiecki i przemysłowy”. 


\section{Mythos i theos}

Główna historiozoficzna i metafizyczna oś interesującego Norwida procesu możliwa jest do zrekonstruowania dzięki bacznej lekturze jego dwóch ostatnich tragedii. Poeta w 1877 roku przygotowywał (niemal symultanicznie) dwa utwory, z których jeden miał wysłać na organizowany w Krakowie konkurs dramatyczny ${ }^{15}$. Mowa o białej tragedii Pierścień Wielkiej-Damy oraz o nieukonczonej tragedii historycznej Kleopatra i Cezar. Oba utwory zdają się różnić niemal wszystkim: uniwersum, problematyką, konstrukcją fabularną i gatunkiem. Pisząc Kleopatrę i Cezara, Norwid odniósł się do wielkiej tradycji tragedii historycznej, dokonując twórczej kontaminacji motywów znanych z Juliusza Cezara oraz Antoniusza i Kleopatry Williama Szekspira. Pierścień Wielkiej-Da$m y$ to zaś całkiem udana próba stworzenia nowego gatunku dramatycznego. Poeta we wstępie do utworu wyraźnie sygnalizował swoją intencję - wiek pary i elektryczności potrzebował zupełnie nowej konwencji dramatycznej. Biała tragedia miała stanowić całkowitą opozycję wobec tragedii historycznej (układ fabularny nie zmierza już do krwawej katastrofy, a raczej dąży do mniej jednoznacznej, choć wyjątkowo opresyjnej, śmierci społecznej) oraz wobec synkretycznej tragedii romantycznej (romantyczna symbolika zastąpiona zostaje przez „wielkie Serio" - teatralny i sceniczny konkret manifestujący się w relacjach między aktorami i towarzyszących im gestach ${ }^{16}$ ). Jednak owe różnice po dokładniejszej lekturze okazują się pozorne. Zanim jednak uda się wykazać podobieństwa łączące obie tragedie, trzeba zacząć od scalającego je spojenia. Jest nim pojawiający się w Pierścieniu Wielkiej-Damy cytat sytuacyjny z Kleopatry $i$ Cezara. Gdy reprezentująca upadającą europejską arystokrację główna bohaterka tragedii - Maria Harris - wyjawia elicie zgromadzonej w swym domu plan postawienia w ogrodzie obsadzonego cyprysami sztucznego grobu, jeden z bohaterów - Hrabia Szeliga - odpowiada jej:

To nie swój jest pomysł - to Eg iptian,

Co byli z mumiami ożenieni,

Jedli z nimi, pili, tańcowali -

[...]

To jest pomysł SMUTNY... z tej przyczyny,

Że miewają goludzie wyzuci

Z pewnego uczucia żywotnego... (PWsz V 268) ${ }^{17}$

Co ma wspólnego ofiara libacyjna za zmarłych (zwyczaj rytualnego spożywania posiłków z mumią) z pomysłem postawienia grobu w ogrodzie?

${ }^{15}$ Zob. Kalendarz życia i twórczości Cypriana Norwida, oprac. Z. Trojanowiczowa, E. Lijewska, przy współudziale M. Pluty, t. 2, Poznań 2007, 529-530.

${ }^{16}$ Zob. I. Sławińska, Reżyserska ręka Norwida, Kraków 1971, s. 81.

${ }^{17}$ Wszystkie cytaty z utworów Norwida (poza wierszami z Vade-mecum) podaję za wydaniem: C. Norwid, Pisma wszystkie, zebrał, tekst ustalił, wstępem i uwagami krytycznymi opatrzył J. W. Gomulicki, Warszawa 1971-1976, t. 1-11, s. 13 (odnosząc się do wymienionego wydania, będę posługiwał się skrótem PWsz, jako numer tomu podając cyfrę rzymską, a strony cyfrę arabską). 
Co łączy dekadencję upadającej kultury starożytnego Egiptu z gotycyzującą melancholią XIX-wiecznej arystokratki? Uważam, że tym jednym autocytatem Norwid - co ukazuje jego absolutny geniusz - stworzył wielką historiozoficzną klamrę, ukazując ważny kulturowy proces, który doprowadził do upadku paradygmatu religii ofiarniczych i stworzył znaną nam nowoczesność. Mowa tu o dialektyce przemocy.

Przemoc jest immanentną cechą tragedii antycznej. Żeby zrozumieć, jaką rolę pełni opresja $w$ utworach największych greckich dramaturgów (a w związku z tym w dziełach samego Norwida twórczo czerpiącego z tej tradycji), warto odnieść się do tez stawianych przez Benjamina i Girarda.

Benjamin uważał, że przemoc losu obecna w tragediach antycznych najintensywniej manifestuje się w micie ${ }^{18}$. Jest ona

w swej modelowej postaci [...] nagą manifestacją bogów. Nie środkiem do ich celów, raczej nie manifestacją ich woli, lecz w pierwszej kolejności manifestacja ich bytu ${ }^{19}$.

Przemoc mityczna stanowi więc przede wszystkim demonstrację władzy bogów nad losem człowieka. Jej celem nie jest jednak władza sprawiedliwa, „która za dobre wynagradza, a za złe karze”. Przemoc mityczna, według Benjamina, nie uznaje niewinności człowieka wobec boskiej władzy:

I tak - by wskazać typowy porządek - nieszczęście spowodowane przez los postrzega się jako reakcję Boga czy bogów na religijną przewinę. A przecież powinno nam dać do myślenia, że nie istnieje analogiczny związek pojęcia losu z pojęciem, które w moralności dane jest równocześnie z kategorią winy - a mianowicie pojęciem niewinności. W klasycznym, greckim ujęciu idei losu nie postrzega się bynajmniej szczęścia, które jest udziałem człowieka, jako potwierdzenia niewinności jego życia, lecz jako pokusę najpoważniejszej przewiny, czyli hybris. Los nie pozostaje zatem w związku z niewinnością ${ }^{20}$.

Benjamin zauważa, że porządek, w którym nie istnieją kategorie niewinności, sprawiedliwości i z którego niepodobna wyobrazić sobie wyzwolenia, nie może być uznawany za porządek religijny ${ }^{21}$ :

Zasady losu - nieszczęście i winę - prawo czyni miarą człowieka; błędem byłoby przyjąć, że w kontekście prawa należy mówić tylko o winie; można wykazać, że wszelka prawna wina jest niczym innym jak nieszczęściem²2.

${ }^{18}$ W. Benjamin, Przyczynek do krytyki przemocy, przeł. A. Lipszyc, [w:] tenże, Konstelacje. Wybór tekstów, przeł. A. Lipszyc, A. Wołkowicz, Kraków 2012, s. 87.

${ }^{19}$ Tamże, s. 87.

${ }^{20}$ Tenże, Los $i$ charakter, przeł. A. Lipszyc, [w:] tenże, Konstelacje. Wybór tekstów, przeł. A. Lipszyc, A. Wołkowicz, Kraków 2012, s. 63.

${ }^{21} \mathrm{O}$ modernistycznych zmaganiach z owym porządkiem przemocy mitycznej skrywającym się za uniwersum religii chrześcijańskiej zob. A. de Jonge, Nightmare culture. Lautréamont and the "Chants de Maldoror", New York 1973.

${ }^{22}$ W. Benjamin, Los i charakter, s. 64. 
Przemoc mityczna jest więc w swej istocie przemocą prawną. Antyczne mity - szczególnie te poświęcone Niobe i Prometeuszowi - stanowią parabolę stosunków prawnych panujących $\mathrm{w}$ greckich polis. Zwracali na to uwagę badacze zajmujący się recepcją antycznych tragedii w epoce romantycznej ${ }^{23}$. Przemoc mityczna jest $\mathrm{w}$ istocie przemocą prawną. Na tym etapie rozważań pojawia się jednak zasadnicza wątpliwość. Dlaczego prawo - jak uważa Benjamin - miałoby się opierać na przemocy nieuznającej niewinności? Dlaczego tym, co rozróżnia porządek religijny od porządku prawnego, jest właśnie kwestia niewinności? Odpowiedź dał sam Benjamin, ale najpierw warto jej poszukać u innych badaczy przemocy mitycznej.

Girard - podobnie jak autor Przyczynku do krytyki przemocy - analizował greckie tragedie pod kątem przemocy mitycznej. Koncentrując się na lekturze Króla Edypa Sofoklesa, postawił tezę, wedle której główny bohater pełni w tragedii rolę kozła ofiarnego. Celem rytuałów ofiarniczych w każdym społeczeństwie jest, według Girarda, hierarchizacja i ustanowienie panowania. Członkowie społeczeństw, dążąc do zdobycia władzy oraz odpowiednio wysokiej pozycji, sięgają po wzajemną opresję, która grozi ogólnemu porządkowi i może doprowadzić do całkowitego rozkładu życia publicznego i prywatnego. Dlatego niezbędny jest mechanizm, który jednym gestem powstrzyma przemoc i doprowadzi do systematyzacji relacji społecznych. Tym mechanizmem jest przemoc rytualna - musi zostać wybrany kozioł ofiarny - najczęściej niewinna ofiara, na której ogniskuje się nienawiść całego społeczeństwa. Istotą przemocy ofiarniczej jest przede wszystkim jej rytualność - nie ma ona charakteru anarchicznego, nie działa ślepo, a podporządkowana jest bardzo sztywnym regułom. Owe reguły są niezbędnym warunkiem jej powodzenia. Akt ofiary staje się więc zwycięstwem porządku nad chaosem, prawa nad bezprawiem, władzy nad poddanymi - jest ostateczną manifestacją władzy i prawa. Oczywiście, przemoc ofiarnicza, mimo swojego charakteru normatywizującego stosunki społeczne, musi zachować pozory sakralności. W przeciwnym razie ów brutalny mechanizm musiałby zostać odsłonięty wraz ze wszystkimi swoimi zasadami, z których najważniejszą jest niewinność ofiary. Istotą przemocy rytualnej nie jest bowiem zemsta bądź wzbudzenie przerażenia ${ }^{24}$. Moralna nieskazitelność baranka stanowi ochronę przed dalszą intensyfikacją przemocy oraz „oczyszcza” jej rytualny wariant:

Rytuał ma na celu „oczyszczenie” przemocy, "oszukanie” jej, skierowanie jej na ofiary, które nie kryją w sobie ryzyka zemsty. Rytuał, jako że umyka mu sekret własnej skuteczności, stara się operować na poziomie substancji i obiektów zdolnych do przyjmowania funkcji symbolicznych ${ }^{25}$.

${ }^{23}$ O romantycznej recepcji tragedii Ajschylosa Prometeusz w okowach zob. M. D. Purinton, Romantic Ideology Unmasked: The Mentally Constructed Tyrannies in Dramas of William Wordsworth, Lord Byron, Percy Shelley, and Joanna Baillie, Delaware 1994.

${ }^{24} \mathrm{O}$ zaraźliwości zemsty i strachu zob. M. Foucault, Nadzorować $i$ karać. Narodziny więzienia, przeł. i posł. T. Komendant, Warszawa 1993, s. 71-74.

${ }^{25}$ R. Girard, Sacrum i przemoc, przeł. M. i J. Plecińscy, cz. 1, Poznań 1994, s. 48. 
Samo „oczyszczenie” pozwala zaś na ustanowienie władzy - zastąpienie anarchicznej przemocy wzajemnej uporządkowaną przemocą prawną. Tym samym przemoc sakralna jest $\mathrm{w}$ istocie początkiem przemocy prawnej. Mit staje się prawem. Przemoc mityczna nie może jednak wiecznie konstytuować władzy. Prędzej czy później nadchodzi moment, w którym składanie niewinnej ofiary traci swą ochronną moc. Kiedy kozioł ofiarny przestaje skupiać na sobie przemoc wzajemną, nie prowadzi już do jej rozładowania, ma, według Girarda, miejsce tzw. kryzys ofiarniczy. Rytuał traci swoją ochronną moc, doprowadzając do atrofii prawa i władzy:

Rozkład mitów i rytuałów, czyli myśli religijnej w aspekcie całościowym, nie następuje wskutek nagłego pojawienia się nagiej prawdy, lecz wskutek nowego kryzysu ofiarniczego ${ }^{26}$.

Właśnie o tym rozkładzie mowa jest w Królu Edypie Sofoklesa. Autor Prawdy powieściowej i kłamstwa romantycznego uważał, że stanowiąca punkt wyjścia $\mathrm{w}$ utworze epidemia jest $\mathrm{w}$ istocie metafora powrotu przemocy wzajemnej, będącą efektem kryzysu ofiarniczego ${ }^{27}$. Podobną, choć o wiele bardziej dosłowną metaforą jest zbrodnia, jaką popełnił Edyp - przemoc wzajemna dotyka fundamentów społeczeństwa i rodziny, doprowadzając do całkowitego rozpadu więzi międzyludzkich. Wspólnotę dotyka dezintegracja uderzająca w jej fundament. Przywrócenie porządku wymaga zaś aktu ofiarniczego. Ponieważ jednak kryzys ofiarniczy zanegował kompensacyjną funkcję ofiary niewinnej, potrzebny będzie nowy klucz jej wyboru. Edyp jest królem, który dzięki swej pozycji „izolowany jest od reszty i tkwi ponad podziałami społecznymi"28. Złożenie go na ołtarzu nie spotka się z vendettą społeczeństwa (nie stanowi bowiem jego części, tkwiąc ponad nim) - utrzymany zostanie więc "oczyszczający" charakter rytuału. Jednakże złożenie Edypa w ofierze jest również swoistym gestem kary. Nie jest to wyrok za popełnioną zbrodnię (Edyp nie był przecież świadom morderstwa ojca i swego kazirodczego związku z matką). Jak już wspomniałem za Benjaminem i potwierdzały to tezy Girarda, przemocy mitycznej, sakralnej, nie interesuje wina bądź jej brak. Istotna jest dla niej tylko skuteczność. Edyp karany jest przez społeczeństwo niezadowolone z tego, że jako przywódca Teb nie był w stanie uchronić swoich poddanych przed anarchią. Okazuje się więc, że przemoc mityczna pełni swoistą rolę regulacyjną - gdy zawodzi ukonstytuowana władza stanowiąca prawo, potrzebny jest mechanizm nadrzędny, przywracający utracony porządek. Nieskutecznego Edypa zastąpi Kreon, który na chwilę przywróci ład. Powracający później kryzys ofiarniczy (wojna domowa pomiędzy Polinejkesem i Eteoklesem) będzie zaś wymagał nowej ofiary.

Zarysowany mechanizm określam mianem dialektyki przemocy. Mit staje się prawem dzięki przemocy mitycznej, następnie prawo ulega mityzacji (gdy przestaje być skuteczne) - władza wymierza rytualne ostrze w samą siebie (król staje się kozłem ofiarnym). Zostaje przywrócony porządek - mit

\footnotetext{
${ }^{26}$ Tamże, s. 174.

${ }^{27}$ Tamże, s. 107.

${ }^{28}$ Tamże, s. 17.
} 
znowu może okrzepnąć w prawo - aż do momentu kolejnego kryzysu. Ów zaklęty krąg dialektyki przemocy może być jednak skutecznie przerwany. Jak zauważył bowiem Benjamin, najskuteczniejszą alternatywną dla przemocy mitycznej jest przemoc boska:

Przemoc mityczna to przemoc krwawa, wywierana na nagim życiu gwoli niej samej, przemoc boska natomiast to przemoc czysta, wywierana na całym życiu gwoli tego, co żyje. Ta pierwsza żąda ofiar, ta druga je przyjmuje ${ }^{29}$.

Tylko przemoc boska ma moc zniesienia przemocy mitycznej i konstytuowanego przez nią prawa:

O ile przemoc mityczna ustanawia prawo, o tyle przemoc boska prawo unicestwia bez granic, o ile ta pierwsza jest krwawa, o tyle ta druga niesie śmierć w sposób bezkrwawy ${ }^{30}$.

Przemoc boska oczekuje dobrowolnej niewinnej ofiary. Nie jest narzędziem tworzenia prawa (tak jak przemoc mityczna), lecz znosi owo prawo, obiecując człowiekowi wyzwolenie. Wyzwolenie, które może zapewnić tylko dobrowolne (!) poświęcenie jednostki gotowej wyswobodzić społeczeństwo spod miażdżących je mechanizmów dialektyki przemocy. Przemoc boska służy człowiekowi, przemoc mityczna służy sobie samej. Tym samym Benjamin - podobnie jak później Girard - wskazuje, że tylko idea mesjaniczna, idea dobrowolnej ofiary, może uchronić społeczeństwo od przemocy wzajemnej. Żeby zrozumieć istotę owej idei mesjanicznej, warto odwołać się historii Chrystusa antycypowanej przez ofiarę Izaaka.

Søren Kierkegaard w Bojaźni i drżeniu zinterpretował wydarzenia na górze Moria jako realizację teleologicznego zawieszenia etyki. Polega ono na odwołaniu reguł normatywizujących życie społeczne (gr. ethos) przez

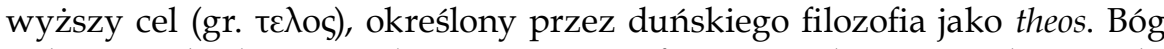
nakazuje Abrahamowi złożenie syna w ofierze. Zgodnie z zasadami etyki życia społecznego - dobrego obyczaju regulującego wzajemne relacje i chroniącego społeczność przed rozpadem - gdyby Abraham zgodził się wykonać nakaz Boga, musiałby zostać postawiony poza nawiasem swojej społeczności. Oczywiście jego czyn byłby zaakceptowany, gdyby ofiara z Izaaka służyła społeczeństwu, to znaczy miałaby charakter przemocy mitycznej. Jednak ani w Piśmie Świętym, ani na kartach Bojaźni i drżenia nie ma mowy o jakichkolwiek społecznych niepokojach, które usprawiedliwiałyby złożenie ofiary z Izaaka. W związku z tym taki czyn traciłby (rytuał ostatecznie nie dokonał się, Abraham na rozkaz Boga cofnął ostrze w ostatniej chwili) ową wspominaną przez Girarda cechę „oczyszczającą" i byłby zwykłym pozbawionym sensu mordem. Śmierć Izaaka nie miałaby więc charakteru utylitarnego, który byłby zrozumiały i godny zaakceptowania. Nakaz Boga wydaje się więc bezsensowny. Według Kierkegaarda, ma on właśnie taki

\footnotetext{
${ }^{29}$ W. Benjamin, Przyczynek do krytyki przemocy, s. 90.

${ }^{30}$ Tamże.
} 
być. Racje boskie są bowiem skrajnie niezrozumiałe. Ich uznanie stawia człowieka w obliczu absurdu:

Mamy tu do czynienia ze specjalnym przypadkiem dialektyki sacrum: profanum zostaje tu przemienione $\mathrm{w}$ sacrum, przy jednoczesnym zachowaniu swej pierwotnej struktury [...]. Dzieciobójstwo nie przemienia się tu w rytuał, którego wypełnienie ma zagwarantować konkretny skutek [...]. Można by powiedzieć, że Abraham nie wątpił w „,sakralność" swego gestu, choć nie „podlegała ona poznaniu, a przeto była niepoznawalna”" ${ }^{31}$.

Eliade zwrócił uwagę, że choć Abraham postrzegał nakaz Boga jako nakaz sakralny, nie rozumiał jego sensu. Gdy Abraham zgodził się złożyć syna $\mathrm{w}$ ofierze, jednocześnie nie rozumiejąc sensu tego czynu, uznawał theos za nadrzędne prawo - przyjął supremację Absolutu. Przemoc boska, którą na potrzeby tych rozważań lepiej byłoby określić mianem supremacji teologicznej, okazuje się nadrzędna wobec przemocy mitycznej. Bóg dlatego wybiera ofiarę z Izaaka - kozła ofiarnego - by wypróbować posłuszeństwo Abrahama. Jej celem jest postawienie Patriarchy w obliczu dwóch perspektyw: prawa przemocy mitycznej i prawa supremacji teologicznej. Abraham jako pierwszy Patriarcha tkwił jeszcze w paradygmacie kultury opartej na przemocy mitycznej. Bóg przemówił więc do niego dobrze znanym Patriarsze językiem symbolicznym, wymagając jednocześnie ostatecznego poświęcenia - zgody wyjścia poza ten dyskurs ku temu, co nieznane.

Wydarzenia na Morii są jednocześnie zapowiedzią ofiary Chrystusa ${ }^{32}$. Mesjasz złożył ofiarę z samego siebie po to, by ostatecznie zadać klęskę mitycznej opresji napędzanej dialektyką przemocy. Jako niewinny baranek zdawał się idealnie spełniać rolę kozła ofiarnego, jednak jego ofiara nie miała już charakteru „oczyszczającego":

Ewangelie obalają, zdaniem Girarda, system ofiarniczy, same więc nie mogą mieć charakteru ofiarniczego. Dlatego autor Kozła ofiarnego zdecydowanie odrzuca interpretację śmierci Chrystusa jako ofiary złożonej przez Chrystusa na żądanie Ojca. W Rzeczach ukrytych od założenia świata polemizuje z zawartą w Liście do Hebrajczyków a rozwiniętą przez teologię średniowieczną tezą o ofierze złożonej przez Chrystusa dla przebłagania zagniewanego Boga, który domaga się najcenniejszej i najdroższej dla niego ofiary ze swojego Syna. Interpretacja ofiarnicza śmierci Jezusa stoi zdaniem Girarda w sprzeczności z nauką o Królestwie Bożym, w której

${ }^{31} \mathrm{M}$. Eliade, Historia wierzeń i idei religijnych, t. 1: Od epoki kamiennej do misteriów eleuzyńskich, przeł. S. Tokarski, Warszawa 2007, s. 183-184.

${ }^{32}$ Zob. S. Budzik, Czy Chrystus byt "kozłem ofiarnym"? René Girard i jego interpretacja ofiary, "Studia Theologica Varsaviensia” 1997, nr 35, s. 66: „Opowiadając się jednoznacznie po stronie prześladowanych ofiar, demaskuje Ewangelia ofiarniczy charakter kultury zbudowanej na religiach wyrosłych z założycielskiego mordu. Według Girarda ukrzyżowanie Chrystusa jest końcem wszystkich dotychczasowych ofiar, tą ostatnią ofiarą, która ukazuje i objawia absurdalność wszelkich innych ofiar". 
Bóg przedstawiony jest jako wszechobejmująca miłość a Jezus jako jej ucieleśnienie i objawienie ${ }^{33}$.

Kiedy, analizując Girardowskie poglądy na śmierć Mesjasza, Budzik mówi, że „,autor Kozła ofiarnego zdecydowanie odrzuca interpretację śmierci Chrystusa jako ofiary złożonej przez Chrystusa na żądanie Ojca", potwierdza tezę postawioną przez Benjamina:

Przemoc mityczna to przemoc krwawa, wywierana na nagim życiu gwoli niej samej przemoc boska natomiast to przemoc czysta, wywierana na całym życiu gwoli tego, co żyje. Ta pierwsza żąda ofia r, ta druga je przyjmuje [podkr. M. G.] $]^{34}$.

Supremacja teologiczna nie żąda ofiary, ale ją pokornie przyjmuje. Chrystus nie jest zmuszony, by stać się kozłem ofiarnym. On sam decyduje się na dokonanie tego heroicznego czynu. Dobrowolnie przyjmuje tę rolę, by jako najniewinniejsza z ofiar obnażyć mechanizmy przemysłu ofiarniczego. Śmierć Chrystusa na krzyżu zadała ostateczny kłam „oczyszczającej” funkcji krwawych obrzędów, ukazując ich bestialstwo. Śmierć Mesjasza ma więc charakter ofiarniczy, jednocześnie nie będąc ofiarą. Mesjasz staje się kozłem ofiarnym nie po to, żeby przebłagać swego Ojca, lecz by wyzwolić ludzkość spod trybów przemocy mitycznej. Supremacja teologiczna - przyjęta przez Abrahama i ustanowiona przez Chrystusa - dąży więc do ostatecznego powstrzymania procesu dialektyki przemocy.

Etapy dialektyki przemocy: jej początek, przesilenie w następstwie kryzysu ofiarniczego oraz upadek i powrót ukazał Norwid w dwóch wspomnianych tragediach. Ich analiza porównawcza pozwoli ukazać instrumentarium intelektualne, które umożliwiło poecie w pełni pojąć istotę rodzącej się na jego oczach późnej nowoczesności.

\section{Tragedie ofiarnicze}

Na początku rozważan o mythos i theos wspomniano o autocytacie sytuacyjnym z Kleopatry i Cezara umieszczonym przez Norwida w Pierścieniu Wielkiej-Damy. Warto odtworzyć bogaty kontekst tego fragmentu, odnosząc się bezpośrednio do monologu tytułowej bohaterki tragedii historycznej. Monolog Kleopatry wygłoszony bezpośrednio do zasiadającej z nią przy stole mumii można intepretować jako część ofiary libacyjnej:

\section{KLEOPATRA}

[...]

Śmiej się im w parze ze mną! - z niewiastą umarłą,

Która istnego męża nie widziała nigdy,

Lub w błędzie jest mniemając, że widzialnym byłby!

\footnotetext{
${ }^{33}$ Tamże.

${ }^{34}$ W. Benjamin, Przyczynek do krytyki przemocy, s. 90.
} 
przestając jedzenie

Miałażbym serce, które sobie uroiło,

Że kochać można wielką miłością na zawsze?

Lub jestże to tytańskim przeciw niebu szałem?

Ideał czuć, co nie był uciosany w kamień... (PWsz V 26)

I dalej:

Szechero! jestem smętna, jak nowo-wyryty

149

W granicie grób, na kogoś czekający - - Pragnę!

posuwa kielich, który napetniaja podczaszowie

Nie! - tego nie chcę wina - idzie tu przez morze,

Siły nabiera, tracąc natomiast kwiecistość.

Jedną poziomkę, właśnie zerwaną z kroplami

Rosy, przenoszę nad ten ociężały nektar.

- Wody pragnę, co granit ma za dno i niebo

Leżące jak w zwierciadle! - lub co pragnę? - nie wiem... (PWsz V 27)

Według analizującej Kleopatrę i Cezara Joanny Trzcionki zacytowany fragment nasycony jest biblijną symboliką:

metafora świeżo „wyrytego grobu”, biblijna aluzja i idący, co siły nabiera, ale „traci kwiecistość”, zmuszają niejako do wydłużenia linii interpretacyjnej o wizję nadchodzącego Jezusa i Jego odkupieńczej ofiary oraz zbliżającego się wraz z nim chrześcijaństwa, które wchłonie obie starożytne cywilizacje ${ }^{35}$.

Badacze wcześniej analizujący ostatnią tragedię historyczną Norwida interpretowali figurę „męża istnego” wyczekiwanego przez Kleopatrę jako antycypację mającego pojawić się w następnej scenie Cezara ${ }^{36}$. Niemniej teza postawiona przez Trzcionkę wydaje się bliższa kontekstowi, w jakim poeta umieścił monolog Kleopatry. Egipt rządzony przez ostatnią reprezentantkę dynastii Ptolemeuszy niszczony jest przez wojnę domową toczoną pomiędzy Kleopatrą i jej bratem. Wojnę domową zaś, podobnie jak epidemię dżumy, można traktować jako metaforę kryzysu ofiarniczego - przemoc wzajemna narasta w społeczeństwie starożytnego Egiptu do poziomu, który doprowadza do bratobójczych walk i całkowitej zapaści społecznej oraz politycznej tak niegdyś potężnego państwa. Bohaterka tragedii Norwida wydaje się zaś w pełni świadoma swej bezradności wobec owego kryzysu. W toku narracji poeta ukazuje głęboką anagnorezę Kleopatry, która uświadamia sobie umowność spełnianej przez siebie roli. We fragmencie dramatu poprzedzającym płomienny monolog, królowa na prośbę głównodowodzącego jej armii odprawia tajemny rytuał, którego celem jest uczynienie go rodowitym [sic!] Egipcjaninem. Absurdalność ceremonii, w której

${ }^{35}$ J. Trzcionka, Norwid - poeta liryczny jako autor dramatów, Warszawa 2010, s. 45.

${ }^{36}$ Zob. I. Sławińska, O komediach Norwida, Lublin 1953, s. 209; E. Żwirkowa, Tragedia kultur. Studium o tragedii historycznej C. K. Norwida "Kleopatra i Cezar”, Lublin 1991, s. 53. 
urodzony w Grecji żołnierz ma zmienić swą tożsamość, przypieczętowana jest fragmentem „Ksiąg Hermejskich” odczytanych przez bohaterkę:

- Tak, z ogrodu kiedy

Kradnie owoc ogrodnik leniwy drugiemu

Ogrodnikowi, rad by swoje własne ślady

Nóg swoich zatrzeć nogą swą, jakby nie swoją,

I trop swój, jako tego, co kradł, podeptać...

- Stąd, i przeto, jest kasta: aby jeden człowiek

Śród zazdrosnych oparł się o zazdrość szeroką

Całej kasty..."

zamyka księge - tyka Rycerza berłem - i porzuca mu łańcuch złoty na szyje

... Rycerzu! Jesteś - z kasty wodzów. (PWsz V 20)

Zacytowany urywek poprzez nasycenie ironią demistyfikuje odprawiony przez Kleopatrę rytuał. Warto odnieść się do tezy Ireny Sławińskiej, wedle której w późnych dramatach autora Kleopatry i Cezara „ironiczny wydźwięk ma [...] wszelki kontrast między prawdziwym a konwencjonalnym znaczeniem słowa" ${ }^{\prime 3}$. Konwencjonalny sens rytuału to zmiana tożsamości Rycerza - przemiana Greka w Egipcjanina. Sens prawdziwy sprowadza się zaś do awansu w hierarchii społecznej. Rycerz-Grek nie jest bowiem szanowany przez podlegających mu oficerów właśnie dlatego, że nie jest rodowitym Egipcjaninem. Religijny rytuał ma zamknąć usta wszystkim krytykom generała i pozwolić mu w pełni dowodzić armią Kleopatry. Ta sytuacja dokładnie ilustruje zauważony przez Benjamina brak różnicy pomiędzy prawem religijnym i prawem sakralnym/mitycznym w społeczeństwach przedchrześcijańskich. Religijny rytuał, który może być odprawiony tylko przez najwyższą kapłankę kultu Izydy - na co kilkakrotnie wskazuje Norwid jako na cechę konstytutywną Kleopatry - ma jednocześnie charakter aktu prawnego; jest swoistym nadaniem Rycerzowi pełni praw obywatelskich. Poprzez zabieg ironizacji Norwid rozbija ową nienaruszalną symbiozę pomiędzy tym, co religijne, i tym, co prawne. Warto jednak mieć na uwadze, że symbiotyczność tej relacji jest pozorna. Jak zauważył cytowany już Girard, relacja pomiędzy prawem a sacrum jest relacją nierówną - przemoc prawna wykorzystuje kostium religijny (święty rytuał składany bogom, niewinna ofiara etc.) do oczyszczania generowanej przez siebie opresji. Ową świadomość nierówności relacji pomiędzy prawem i religią w kulturze opartej na przemocy mitycznej Norwid wcielił w postać głównej bohaterki Kleopatry i Cezara.

Żeby zamknąć rytuał Kleopatra dotyka głowy Sfinksa. Sfinks zaś reprezentuje w utworze Norwida umarły, spetryfikowany w kamień panteon starożytnego Egiptu:

... Sfinks jest Sfinksem,

On, który się uśmiecha w swoje własne usta

I powstrzymuje wyraz własnej twarzy...

${ }^{37}$ I. Sławińska, O komediach Norwida, Lublin 1953, s. 222. 
dotyka palcem głowy Sfinksa

... lecz we wnętrzu

On sam jest - szczerym kamieniem: nic więcej!...

potrąca krótką włócznia tarcze

Słudzy nasi, czy jeszcze są sługami?!! - pytam. (PWsz V 13)

Owe słowa są pierwszymi wypowiadanymi przez Kleopatrę $\mathrm{w}$ tragedii. Od samego początku Norwid buduje jej charakterystykę jako osoby w pełni świadomej kryzysu ofiarniczego niszczącego jej państwo. Co więcej, Królowa wie, że umarłe sacrum jej religii nie oferuje już żadnych narzędzi pozwalających na powstrzymanie kryzysu. Pozostaje jej więc mechaniczne odprawianie ceremonii, mających podtrzymać wrażenie stanowienia władzy. Owa mechaniczność zaś stanowi jej jedyny ratunek przed śmiercią. Kryzys ofiarniczy - co ukazał Sofokles w Królu Edypie - w ostateczności sięga przecież po samego władcę. Dlatego Królowa sprawuje religijne ceremonie, nie wierząc w ich sens. Osamotnienie i świadomość fasadowości sprawowanych przez nią funkcji doprowadzają bohaterkę do pogłębiającej się inercji. Narastająca bierność, poczucie niemocy i melancholii w pełni charakteryzują postawę Kleopatry wobec rzeczywistości. I kiedy wydawałoby się, że nie ma dla niej ratunku, królowa dostaje nagłego objawienia. Objawienia, które odzwierciedla się w jej mesjanicznym pragnieniu spotkania Tego, Który jako jedyny może zatrzymać obłęd dialektyki przemocy.

Obietnica mesjaniczna powraca wielokrotnie w Kleopatrze i Cezarze, za każdym razem ewokowana w symbolice wina i krwi. Warto tu wspomnieć o najciekawszej realizacji tego wątku w utworze - ostatnim toaście Marka Antoniusza. Bohater, każąc służącemu oczyścić poplamioną krwią ostrogę, wznosi swój ostatni toast:

Daj mi kielich -

Sam - miecza dobądź i raz wtóry

Szczęścia popróbuj... uderz!... ugodź!...

HER

...Co ja słyszę!

MAREK ANTONIUSZ

Słyszysz czas odchodzący - przeszły - a zrąbię cię

Jak psa - rycerzu nowy! - gdy cofniesz się - - dalej!!

HER

wychyla gwattownie swój kielich i rusza ze szpada

W obronie własnej!...

przebija Antoniusza

ANTONIUSZ

konając potrąca rękę Hera

...Zdrów... bądź... rzymski... kawalerze... (PWsz V 156-157) 
Zanim jednak zginie, w tej samej scenie, wieńcząc swój ostatni toast, wymawia znamienne słowa:

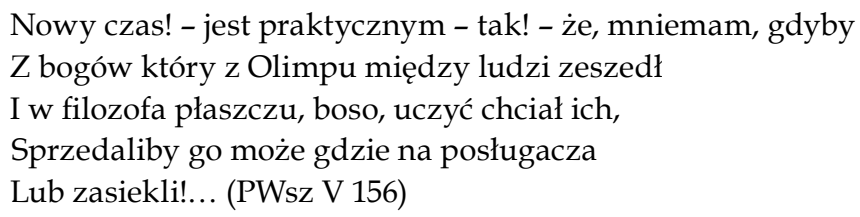

Wino - podobnie jak w monologu Kleopatry - staje się symbolem zapowiadającym zbawczą mękę Chrystusa. Co jednak znamienne, w ostatnim monologu Antoniusza zauważalna jest istotna dla rytuałów ofiarniczych wymienność wina i krwi:

W Rzymie mleko, wino i krew są przedmiotem potrójnej libacji, którą czyni się zmarłym. [...] Płyny wymienne, które krążą i z łatwością przemieniają się w siebie nawzajem, przy czym nierzadko zmiana ta stanowi złą wróżbę ${ }^{38}$.

Plama krwi/wina i ostatni toast pełnią podwójny charakter: są fatalistycznym omenem śmierci Antoniusza oraz optymistyczną zapowiedzią nadejścia Chrystusa. Norwid tak skonstruował tę scenę, by pokazać, że ów fatalizm i optymizm są nierozłączne - bohaterowie tkwiący w paradygmacie przemocy mitycznej, dając świadectwo obietnicy mesjanicznej, skazują siebie na zagładę, jednocześnie zapowiadając kres przemysłu ofiarniczego. Śmierć Antoniusza ma więc charakter samoofiarowania. Bohater dobrowolnie przyjmuje rolę kozła ofiarnego nie po to, by stłumić kryzys ofiarniczy, ale by zapowiedzieć jego kres. Ten schemat ofiarniczej zapowiedzi supremacji teologicznej pojawił się po raz pierwszy w twórczości Norwida w napisanym w 1851 roku jednoaktowym dramacie Wanda. Królowa Słowian składała ofiarę z samej siebie, zapowiadając nadejście Chrystusa:

WANDA

Dobrzy ludzie!... widziałam cień ogromny Boga,

Przechodzący po polach jak szeroka droga,

A to był tylko ręki jeden cień - ta ręka

Jakby przemytą była, bo słońce padało

Przez wnętrze dłoni, na wskroś, jak przez wypaść sęka.

I stałam - i patrzyłam $\mathrm{w}$ to rozdarte ciało,

Jak ptak z ciemności w jasną pogląda szczelinę,

I dano mi je widzieć - to...

Bierze gromnice zapalona z rąk Piasta i wchodzi na stos - potem, ciszej, kończy

...że dla was zginę... (PWsz IV 155-156)

${ }^{38}$ J-P. Roux, Krew. Mity, symbole, rzeczywistość, przeł. M Chrobak, Kraków 2013, s. 306. 
I dalej:

... Każdy rozrzewnił się szczerze

I przyniósł, na co stać mu... to jest dość na wieki

Żywota dla was... dziwni będą z was żołnierze

I Prowe-bóg szczególnej użyczy opieki...

- A co jest ze mnie, dam wam...(PWsz IV 156)

Co prawda, w tym dramacie nie pojawiają się symbole wina/krwi ewokujące ofiarę, jednak znamienny jest tu pewien schemat powtarzany później przez dojrzałego Norwida w Kleopatrze i Cezarze. Niewinny bohater (lub bohaterka) zanurzony $\mathrm{w}$ paradygmacie przemocy mitycznej postanawia w obliczu kryzysu ofiarniczego złożyć z siebie ofiarę. Bohaterowie dają świadectwo wiary w ostateczne wyzwolenie, tym samym zapowiadając nadejście Chrystusa. Wanda, Kleopatra i Marek Antoniusz pełnią - paradoksalnie! - rolę pierwszych (przed)chrześcijańskich męczenników. Ich ofiara czyni z nich bowiem pierwszych chrześcijan - tych, którzy nie znając Chrystusa, a li tylko go przeczuwając, poszli za nim. Norwid już w wykładach poświęconych Juliuszowi Słowackiemu pisał o takich pierwszych chrześcijanach, wymieniając Sokratesa i Juliusza Cezara. W ofiarniczych tragediach autora Pierścienia Wielkiej-Damy ofiara męczeńska jest jednocześnie zapowiedzią i odwzorowywaniem zbawczej męki Chrystusa. Przeszłość i przyszłość zostają zawieszone - prawdziwe sacrum (tak jak w ostatnim Norwidowskim tekście filozoficznym - Milczeniu) działa poza czasem, wyłamując rzeczywistość z jej ukonstytuowanego biegu. Przeszłość świata starożytnego opartego na przemocy mitycznej zostaje niejako unieważniona przez przyszłość kultury opartej na supremacji teologicznej. W tym unieważnieniu przemoc boska znosi przemoc mityczną.

Poeta, chcąc podkreślić ofiarniczy charakter Kleopatry i Cezara, zdecydował się wykorzystać symbolikę krwi i wina. Jest to zgodne z kulturowym obyczajem i wyobrażeniami dotyczącymi ceremonii ofiarniczych:

[o]fiarą nazywa się każdy dar, nawet roślinny, za każdym razem, gdy ów dar lub jego część zostaje zniszczony, chociaż zwyczaj rezerwuje termin ofiara dla znaczenia ofiary krwawej ${ }^{39}$.

Ofiara - jak wskazuje cytat - nie zawsze musi być ewokowana przez symbolikę krwi. Rytuał bezkrwawy, sprowadzający się nie do śmierci fizycznej, lecz społecznej, stanowi główny wątek Norwidowskiej białej tragedii - napisanej w tym samym czasie, co tragedia historyczna, Pierścienia Wielkiej-Damy.

39 "Dans ces conditions, on doit appeler sacrifice toute oblation même végétale, toutes les fois que l'offrande, ou qu'une partie de l'offrande, est détruite, bien que l'usage paraisse réserver le mot de sacrifice à la désignation des seuls sacrifices sanglants" (H. Hubert, M. Mauss, Essai sur la nature et de la fonction du sacrifice, [w:] M. Mauss, CEeuvres, t. 1, Paris 1968, s. 13-14). 
W białej tragedii kontekst wieczerzy Kleopatry, podczas której bohaterka zwraca się z toastem do mumii - symbolu umarłej kultury podtrzymywanej przez mechanizmy dialektyki przemocy - zostaje umieszczony w realiach drugiej połowy XIX wieku. Sceną Pierścienia Wielkiej-Damy jest cała nowoczesna Europa, zaś salon Marii Harrys - tytułowej bohaterki dramatu - stanowi miejsce reprezentatywne, przestrzeń władzy arystokracji, która coraz trudniej odnajduje się $\mathrm{w}$ realiach wieku pary i elektryczności. Dumny europejski arystokrata w obliczu brutalnych mechanizmów kapitalizmu coraz częściej ulegał sprytniejszemu i wyśmienicie dostosowanemu do nowoczesnych realiów mieszczaninowi. Ten mechanizm społecznego

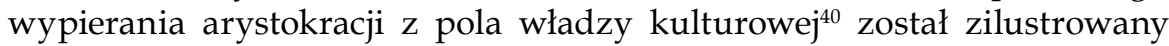
w białej tragedii Norwida w relacji Hrabina Harrys (arystokratka) - Mak-Yks (jej ubogi krewny, intelektualista, arystokrata ducha) - Sędzia Durejko (prawnik, mieszczanin). Niepodzielną władzę w salonie Hrabiny pełni Durejko. To on decyduje o wszystkim, co ma miejsce w rezydencji arystokratki, może nawet eksmitować Mak-Yksa, przed czym nawet Hrabina nie potrafi go powstrzymać. Dlatego właśnie Durejko w zakończeniu dramatu określa siebie ex-machina. Maria Harrys po tym, gdy Sędzia w jej salonie bez jej zgody rozpoczyna policyjne śledztwo, zaczyna zdawać sobie sprawę z tego, że jest $\mathrm{w}$ istocie uzależniona od decyzji podejmowanych przez samowolnego Durejkę. Dlatego bohaterka postanawia wykonać pusty gest podobny temu, który spełniła Kleopatra wobec Rycerza. Harrys odprawia ceremonię zaręczyn i oddaje swoją dłoń Mak-Yksowi. Perspektywa małżeństwa wydaje się ratować bohatera przed eksmisją i zesłaniem przez Durejkę do domu dla obłąkanych, zaś Hrabinie daje iluzję władzy. Sama ceremonia jest jednak steatralizowanym pozorem, co zaakcentował poeta w jej symbolicznym podsumowaniu - pokazie ogni sztucznych:

Zaręczynom towarzyszy jednak, zarządzony przez Hrabinę na koniec przyjęcia, fajerwerk ułożony w pierścień ogni sztucznych, a choć zachwyty zgromadzonych gości („fikcja wyśmienita”, „udanie ogniste”) stanowią komentarze na jego widok, to równie dobrze mogą odnosić się do zrękowin Hrabiny z poetą. Zbieżność sytuacji oraz dwóch pierścieni - sztucznego na niebie i zaręczynowego - nie jest przypadkowa ${ }^{41}$.

Obie bohaterki - Kleopatra z tragedii historycznej i Hrabina Harrys z tragedii białej - znajdują się $\mathrm{w}$ analogicznej sytuacji egzystencjalnej: są reprezentantkami grup społecznych, niegdyś tworzących pole władzy symbolicznej, a w czasach im współczesnych ulegających stopniowej degradacji. Dekadencja właściwa Kleopatrze - ów „brak uczucia żywotnego” - objawia się w sentymentalno-gotyckim pragnieniu Hrabiny otaczania się instrumentarium śmierci: grobami i cyprysami. Jest to swoiste powtórzenie gestu Królowej Egiptu kierowanego do mumii w trakcie wieczerzy. Z jedną różnicą. Bowaryzm Kleopatry skłania ją do przekroczenia uniwersum swojej kultury,

${ }^{40}$ Zob. P. Bourdieu, Reguły sztuki, przeł. A. Zawadzki, Kraków 2007.

${ }^{41}$ S. Świontek, Wstęp, [w:] C. Norwid, Pierścień Wielkiej Damy, oprac. S. Świontek, Wrocław 1990, s. XXVI-XXVII. 
do rozbudzenia w sobie marzenia o spotkaniu „męża istnego" - Mesjasza. Dekadencja Hrabiny nie skłania jej do dokonania analogicznego przekroczenia. Jeżeli gest pustego rytuału jest dla Kleopatry wstępem do głębokiej anagnorezy, to dla Harrys jest on gestem ostatecznym. Nie ma bowiem w uniwersum Pierścienia Wielkiej-Damy miejsca na obietnicę mesjaniczną.

Mogłoby się wydawać, że akt supremacji teologicznej - śmierć i zmartwychwstanie Chrystusa - położył ostateczny kres przemocy mitycznej, zatrzymując zaklęte koło dialektyki przemocy. Jednak, jak zauważyli Theodor Adorno i Max Horkheimer, narodziny nowoczesności zaczynają się od restytucji mitu. Jest nim wiara $\mathrm{w}$ dogmat o autoteliczności rozumu instrumentalnego - uważanego $\mathrm{w}$ nowoczesnym europejskim społeczeństwie za ostateczną instancję etyczną. Owo naiwne przekonanie staje się fundamentem rozwoju kultury masowej, etyki życia społecznego, ekonomii i gospodarki. Wszystko podporządkowane zdaje się chłodnemu, zracjonalizowanemu osądowi, który jawi się jako najbardziej obiektywna i sprawiedliwa instancja. Co jednak najgroźniejsze, rozum instrumentalny w praktyce nie staje się narzędziem krzewienia sprawiedliwości, lecz politycznego, ekonomicznego i społecznego wyzysku:

[...] społeczny charakter form myślenia nie jest wyrazem społecznej solidarności - jak uczy Durkheim - ale świadectwem nierozerwalnej jedności społeczeństwa i panowania. Panowanie nadaje społecznej całości, w której zostaje ustanowione, większą spoistość i siłę. Podział pracy, który jest społecznym skutkiem panowania, pomaga przetrwać całości, która podlega panowaniu. Tym samym jednak całość jako całość, jako aktywność jej immanentnego rozumu, siłą rzeczy staje się egzekutorem partykularności. Panowanie występuje wobec jednostki jako to, co ogólne, jako urzeczywistniony rozum. [...] To, co spotyka wszystkich za sprawą niewielu, dokonuje się zawsze jako pokonywanie jednostki przez wielu: ucisk społeczeństwa nosi zawsze znamiona ucisku przez kolektyw $w^{42}$.

Wiara w potęgę i sprawiedliwość rozumu instrumentalnego staje się najważniejszym mitem nowoczesności. Kryzys ofiarniczy zaś może powrócić nie tylko dzięki restytucji mitu zakrywającego niesprawiedliwość tych, którzy dzierżą władzę, wobec tych, którzy są jej pozbawieni. Norwid w Pierścieniu Wielkiej-Damy ukazał coś znacznie bardziej niepokojącego wchłonięcie dialektyki przemocy przez dialektykę oświecenia. Ten proces najlepiej można pokazać na schemacie:

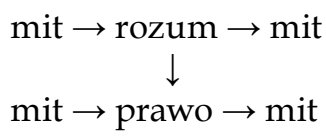

${ }^{42}$ M. Horkheimer i T. W. Adorno, Dialektyka oświecenia, przeł. M. Łukasiewicz, Warszawa 1994, s. 37-38. 
Mit o autotelicznym rozumie jest wspierany przez mit o autotelicznym i niezależnym prawie. To zjawisko najdokładniej opisał Foucault w Nadzorować $i$ karać. Na przełomie XVII i XVIII wieku - czyli również w okresie narodzin mitu o rozumie instrumentalnym - nastąpiła zmiana paradygmatu prawa. Celem kary przestała być już krwawa vendetta władzy, lecz wychowywanie społeczeństwa i zapobieganie przestępstwom. Idea każącej dłoni władcy, zemsty prawa objawiającej się w brutalnych egzekucjach i torturach, zastąpiona została złożonym systemem placówek o charakterze penitencjarnym i wychowawczym. Owe przemiany zaś tłumaczone były przez reformatorów chęcią jak największej obiektywizacji przepisów. Prawo miało więc działać na chłodno, za pomocą kalkulacji zysków i strat, a największym zyskiem miała być szeroko pojęta inżynieria społeczna, której materialną reprezentacją był opisywany przez Foucaulta panoptykon. Fundamentem prawa stał się rozum instrumentalny, gwarantujący sprawiedliwość i skuteczność. Ten proces miał jednak swoją cenę. Była nią narastająca inwigilacja. Władza zawsze pragnęła zdobyć wiedzę o swoich obywatelach. Kultura zaś coraz wyraźniej zaczęła przypominać wspominany już panoptykon - relacje społeczne podlegały rosnącej inwigilacji przy biernej zgodzie obywateli. Wszyscy obserwują wszystkich i wszyscy podlegają wzajemnej ocenie. Skurczyła się przestrzeń prywatności i intymności ${ }^{43}$. Jednocześnie życie publiczne stało się teatrem gry i pozorów, którego kwintesencją jest fasadowość i kabotynizm życia społecznego i kulturalnego w Paryżu II Cesarstwa. Jak zauważył Krzysztof Trybuś, Pierścień Wielkiej-Damy, nie tylko $\mathrm{w}$ warstwie problemowej, ale również gatunkowej, stanowi sprzeciw wobec tego procesu ${ }^{44}$. Poeta $w$ przestrzeni teatralnych gestów i ciszy szuka wielkiego "Serio" - punktu, z którego wybija prawda rozbijająca konwencję życia salonowego. Norwidowska krytyka nowoczesnego Paryża, nowoczesności per se, jest jednocześnie negatywną oceną powrotu dialektyki przemocy pod postacią dialektyki oświecenia. Ten proces restauracji przemysłu ofiarniczego ukazał Norwid w kreacji jednego z bohaterów białej tragedii - Sędziego Durejki.

Durejko nie jest bowiem tylko mieszczaninem spragnionym władzy. Jest uosobieniem prawa dialektyki przemocy w najczystszej postaci. Wszystkie, nawet najbardziej brutalne i nieludzkie, ze swych poczynań motywuje racjonalizmem i głębokim humanizmem [sic!]. Jest tyranem, któremu jednak pozwala się na wszystko, bowiem reprezentuje władzę najwyższą - prawo ufundowane na rozumie instrumentalnym. Godna podziwu jest również niezwykła praktyczność Sędziego. Wszystko, co wymyka się owej pragmatyczności, zasługuje na zniszczenie. Najważniejszą bowiem dla niego zasadą jest szczególnie pojęty ład i porządek, które chętnie wprowadzi do salonu Marii Harrys, nie cofając się przed niczym. Durejko przestaje być pociesznym błaznem, głupawym mieszczaninem wyjętym żywcem z komedii Moliera, a staje się naprawdę groźny w momencie, gdy w ostatnim akcie wpada z policją do salonu Hrabiny i przy zgromadzonych wypowiada

${ }^{43}$ Mieszkanie jako futerał człowieka zob. W. Benjamin, Pasaże, red. i wstęp R. Tiedemann, przeł. I. Kania, Kraków 2005, s. 40.

${ }^{44}$ K. Trybuś, Norwid w teatrze świata - kilka pytań, „Studia Norwidiana” 1997-1998, s. 15-16. 
zgubną w swych następstwach frazę: „egzekucji nadszedł czas i rygor!” (PWsz VI 272). Ofiarą egzekucji staje się najsłabszy, niepasujący do uporządkowanego świata Durejki, Mak-Yks. Ostatecznie Sędziemu jednak nie udaje się zniszczyć ubogiego rezydenta. Ceremonia zaręczyn odprawiona przez Hrabinę ratuje mu życie - Mak-Yks jako narzeczony arystokratki staje się nietykalny. Gest Hrabiny nie jest jednak aktem samoofiarowania się - oddania ręki Mak-Yksowi - które uratuje go przed śmiercią społeczną (zamknięciem w zakładzie dla obłąkanych, co sugeruje Durejko ${ }^{45}$ ), lecz wręcz przeciwnie - stanowi akt ofiary z samego Mak-Yksa. Hrabina bowiem nie kocha go, czego on jest doskonale świadom. Jej chłód, egoizm i nietakt doprowadzają go niemal do samobójczej śmierci. Hrabina nie ratuje jego, lecz siebie - ocala swoje upadające panowanie, pokazuje zebranym i Durejce, że to ona wciąż dzierży władzę $\mathrm{w}$ salonie, że to do niej należy ostatnie słowo. Podobnie jak w Kleopatrze i Cezarze akt ceremonii służy tylko podtrzymaniu iluzji władzy - iluzji, która niezbędna jest, by władca/arystokrata mógł przetrwać w obliczu kryzysu ofiarniczego.

Ofiarne żertwie zostały ponowione. Społeczeństwo zgromadzone w salonie domaga się niewinnego baranka - staje się nim Mak-Yks. Rytuał zamka się $\mathrm{w}$ symbolicznym obrazie ofiary całopalnej - $\mathrm{w}$ momencie, gdy Mak-Yks zgadza się wbrew własnej woli przyjąć rękę Hrabiny, wybuchają nad sceną sztuczne ognie. Ofiara zostaje spełniona.

Najciekawsze $\mathrm{w}$ dramatach ofiarniczych Norwida jest ujmowanie samego aktu ofiarniczego. W Wandzie rozlew krwi zostaje zastąpiony obrazami stygmatów Chrystusa, który ginie w tym samy czasie, co główna bohaterka. W Kleopatrze i Cezarze ofiara ma głównie zabarwienie symboliczne - toasty Kleopatry i Marka Antoniusza mają charakter eucharystyczny, będąc zapowiedzią obietnicy mesjanicznej. W Pierścieniu Wielkiej-Damy, białej tragedii, której główną cechą (o czym wspomniał poeta we wstępie do utworu) jest brak krwawego zakończenia, ukazany jest powrót dialektyki przemocy $\mathrm{w}$ wariancie zracjonalizowanym, w którym przemysł ofiarniczy obywa się bez rozlewu krwi. Dialektyka przemocy nie potrzebuje już dosłowności, bowiem staje się częścią dialektyki oświecenia, która obietnicę mesjaniczną zastąpiła afirmacją racjonalizacji stosunków międzyludzkich. Jednakże owa racjonalizacja nie łagodzi przemocy, a tylko zmienia jej formę. Mak-Yks staje się kozłem ofiarnym, a jego śmierć ma charakter społeczny - bohater zgadzając się na małżeństwo z Hrabiną, traci swoją niezależność, staje się zakładnikiem jej łaski.

Poprzez ukazanie mechanizmów dialektyki przemocy w dwóch wydawałoby się tak różnych uniwersach - starożytności i nowoczesności - poeta pokazał stopniową erozję kultury opartej na chrześcijańskiej obietnicy mesjanicznej. Późna nowoczesność stanowiła dla poety, pomimo jego fascynacji rozwojem technicznym i naukowym, kulturowy regres najmocniej dotykający realiów życia społecznego. Jednak wbrew właściwego dla Pierścienia

${ }^{45} \mathrm{O}$ tzw. psychiatrii represywnej zob. M. Foucault, Historia szaleństwa w dobie klasycyzmu, przeł. H. Kęszycka, Łódź 1987; B. Brążkiewicz, Psychiatria radziecka jako instrument walki z opozycja polityczną w latach 1918-1984, Toruń 2004; L. Nijakowski, Biowładza w późnej nowoczesności, [w:] Wiedza - władza, red. J. Szymczyk, M. Zemło, A. Jabłoński, Lublin 2009, s 107-125. 
Wielkiej-Damy modernistycznego fatalizmu, który przecież tak dobrze znany jest choćby z Kwiatów zła Baudelaire’a, poeta wciąż wierzył w obietnicę mesjaniczną, w to, co najmocniej wyraził w jednym ze swych najważniejszych wierszy: „O! nieskończona jeszcze dziejów praca, / Nie-prze-palony jeszcze glob, Sumieniem!" (VMFert 2, 16). Ów optymizm, znany przecież nie tylko z wiersza Socjalizm, ale również Kleopatry i Cezara, Tajemnicy lorda Singelworth, Assunty i Milczenia, zbliżał poetę urodzonego w drugiej dekadzie XIX wieku do twórczości takich wielkich modernistów jak Marcel Proust i Thomas Eliot.

\section{B I B LIOGRA F I A}

Benjamin W., Los i charakter, przeł. A. Lipszyc, [w:] tenże, Konstelacje. Wybór tekstów, przeł. A. Lipszyc, A. Wołkowicz, Kraków 2012, s. 63-68.

Benjamin W., Pasaże, red. i wstęp R. Tiedemann, przeł. I. Kania, Kraków 2005. Benjamin W., Przyczynek do krytyki przemocy, przeł. A. Lipszyc, [w:] tenże, Konstelacje, Wybór tekstów, przeł. A. Lipszyc, A. Wołkowicz, Kraków 2012, s. 69-92.

Bourdieu P., Reguły sztuki, przeł. A. Zawadzki, Kraków 2007.

Brążkiewicz B., Psychiatria radziecka jako instrument walki z opozycja polityczna w latach 1918-1984, Torun 2004.

Budzik S., Czy Chrystus byt „kozłem ofiarnym”? René Girard i jego interpretacja ofiary, „Studia Theologica Varsaviensia” 1997, nr 35, s. 49-70.

Eliade M., Historia wierzeń i idei religijnych, t. 1: Od epoki kamiennej do misteriów eleuzyńskich, przeł. S. Tokarski, Warszawa 2007.

Foucault M., Historia szaleństwa w dobie klasycyzmu, przeł. H. Kęszycka, Łódź1987.

Foucault M., Nadzorować i karać. Narodziny więzienia, przeł. i posł. T. Komendant, Warszawa 1993.

Giddens A., Nowoczesność i tożsamość, przeł. A. Szulżycka, Warszawa 2010.

Girard R., Sacrum i przemoc, przeł. M. i J. Plecińscy, cz. 1, Poznań 1994.

Horkheimer M. i Adorno T. W., Dialektyka oświecenia, przeł. M. Łukasiewicz, Warszawa 1994.

Hubert H., Mauss M., Essai sur la nature et de la fonction du sacrifice, [w:] M. Mauss, CEeuvres, t. 1, Paris 1968, s. 193-307.

Jonge A. de, Nightmare culture. Lautréamont and the "Chants de Maldoror", New York 1973.

Kalendarz życia i twórczości Cypriana Norwida, oprac. Z. Trojanowiczowa, E. Lijewska, przy współudziale M. Pluty, t. 2, Poznań 2007, 529-530

Kasperski E., Pseudo-Norwid, czyli co się komu podoba, "Studia Norwidiana" 2014, nr 32, s. 290-325.

Lisiecka A., Norwid - poeta historii, Londyn 1973.

Maciejewski J., Cyprian Norwid, Warszawa 1992.

Nieukerken A. van, W czym zawiera się Norwidowski modernizm?, „Przegląd Humanistyczny" 2014, z. 2, s. 109-117.

Nijakowski L., Biowładza w późnej nowoczesności, [w:] Wiedza - władza, red. J. Szymczyk, M. Zemło, A. Jabłoński, Lublin 2009, s 107-125. 
Norwid C., Pisma wszystkie, zebrał, tekst ustalił, wstępem i uwagami krytycznymi opatrzył J. W. Gomulicki, t. 1-11, Warszawa 1971-1976.

Norwid C., Vade-mecum, oprac. J. Fert, wyd. 2, Lublin 2004.

Purinton M. D., Romantic Ideology Unmasked: The Mentally Constructed Tyrannies in Dramas of William Wordsworth, Lord Byron, Percy Shelley, and Joanna Baillie, Delaware 1994.

Roux J-P., Krew. Mity, symbole, rzeczywistość, przeł. M Chrobak, Kraków 2013. Rymkiewicz J. M., Juliusz Stowacki pyta o godzinę, Warszawa 1989.

Rzepczyński S., Norwid a nowoczesność, [w:] Romantyzm i nowoczesność, red. M. Kuziak, Kraków 2009, s. 205-216.

Samsel K., Premodernizm, dekonstrukcjonizm, „proteuszowość" Norwida. Uwagi na marginesie dyskusji wokót Premodernizmu Norwida - na tle symbolizmu literackiego drugiej połowy XIX wieku i wcześniejszych ksiażek Wiesława Rzońcy, „Świat Tekstów. Rocznik Słupski” 2015, nr 13, s. 101-121.

Siwiec M., Norwid i Baudelaire. Komparatystyka przetomu, [w:] Komparatystyka dzisiaj, red. E. Kasperski i E. Szczęsna, t. 2, Warszawa 2011, s. 248-260.

Sławińska I., O komediach Norwida, Lublin 1953.

Sławińska I., Reżyserska ręka Norwida, Kraków 1971.

Stefanowska Z., Norwidowski romantyzm, [w:] taż, Strona romantyków. Studia o Norwidzie, Lublin 1993, s. 63-83.

Stefanowska Z., Pisarz wieku kupieckiego i przemystowego, [w:] taż, Strona romantyków. Studia o Norwidzie, Lublin 1993, s. 5-53.

Świontek S., Wstęp do C. Norwid, Pierścień Wielkiej-Damy, oprac. S. Świontek, Wrocław 1990.

Trybuś K., Norwid w teatrze świata - kilka pytań, „Studia Norwidiana” 19971998, 9-20

Trzcionka J., Norwid - poeta liryczny jako autor dramatów, Warszawa 2010.

Żwirkowa E., Tragedia kultur. Studium o tragedii historycznej C. K. Norwida "Kleopatra i Cezar", Lublin 1991.

Żurowski M., Norwid i Gautier, [w:] Nowe studia o Norwidzie, red. J. W. Gomulicki i J. Z. Jakubowski, Warszawa 1961, s. 167-190.

\section{STRESZCZENIE}

Wśród badaczy twórczości Cypriana Norwida wciąż żywy wydaje się spór o przynależność autora Pierścienia Wielkiej-Damy do romantyzmu lub modernizmu. Pytanie o nowoczesność Norwidowskiej myśli jest jednocześnie trudnym pytaniem o nowoczesność polskiego romantyzmu. Na ile poeta uwikłany był w artystyczne idee stworzone przez swoich wielkich poprzedników - Mickiewicza, Słowackiego i Krasińskiego - a na ile jego refleksja jest wyjątkowa i przełomowa? W artykule autor postanowił skupić się na ukazaniu późnej Norwidowskiej twórczości dramatycznej jako w pełni podporządkowanej nowoczesnej refleksji, ukazując autora Kleopatry i Cezara jako prekursora koncepcji stworzonych przez tak wybitnych reprezentantów krytyki nowoczesności jak René Girard, Walter Benjamin i Michel Foucault. 


\section{Słowa kluczowe}

nowoczesność; romantyzm; Norwid; tragedia; ofiara

\section{S U M M A RY}

\section{Dialectics of violence in sacrifice tragedies by Cyprian Norwid}

Researchers analysing the literary output by the author of The Ring of a Great Lady (Pierścień Wielkiej Damy) hold a continuous debate on his affinity with Romaticism or Modernism. The question about the modernity of Norwidian thought is at the same time a difficult question about the modernity of Polish Romanticism. To what extent was he involved in the artistic ideas originated by his great predecessors - Mickiewicz, Słowacki and Krasiński - and to what extent is his thought genuinely exceptional and ground-breaking? In the article, its author decides to focus on Norwid's later dramatic output, since it was fully subordinated to modern reflection and presented the author of Cleopatra and Caesar (Kleopatra $i$ Cezar) as a forerunner of concepts coined by such prominent critics of modernity as René Girard, Walter Benjamin and Michel Foucault.

\section{Keywords}

modernity; Romanticism; Norwid; tragedy; sacrifice 